\title{
CAUSES AND EFFECTS OF SPATIAL CHAOS IN THE POLISH CARPATHIANS - A DIFFICULT WAY TO SUSTAINABLE DEVELOPMENT
}

Agata Ćwik ${ }^{1}$, Hanna Hrehorowicz-Gaber ${ }^{2}$

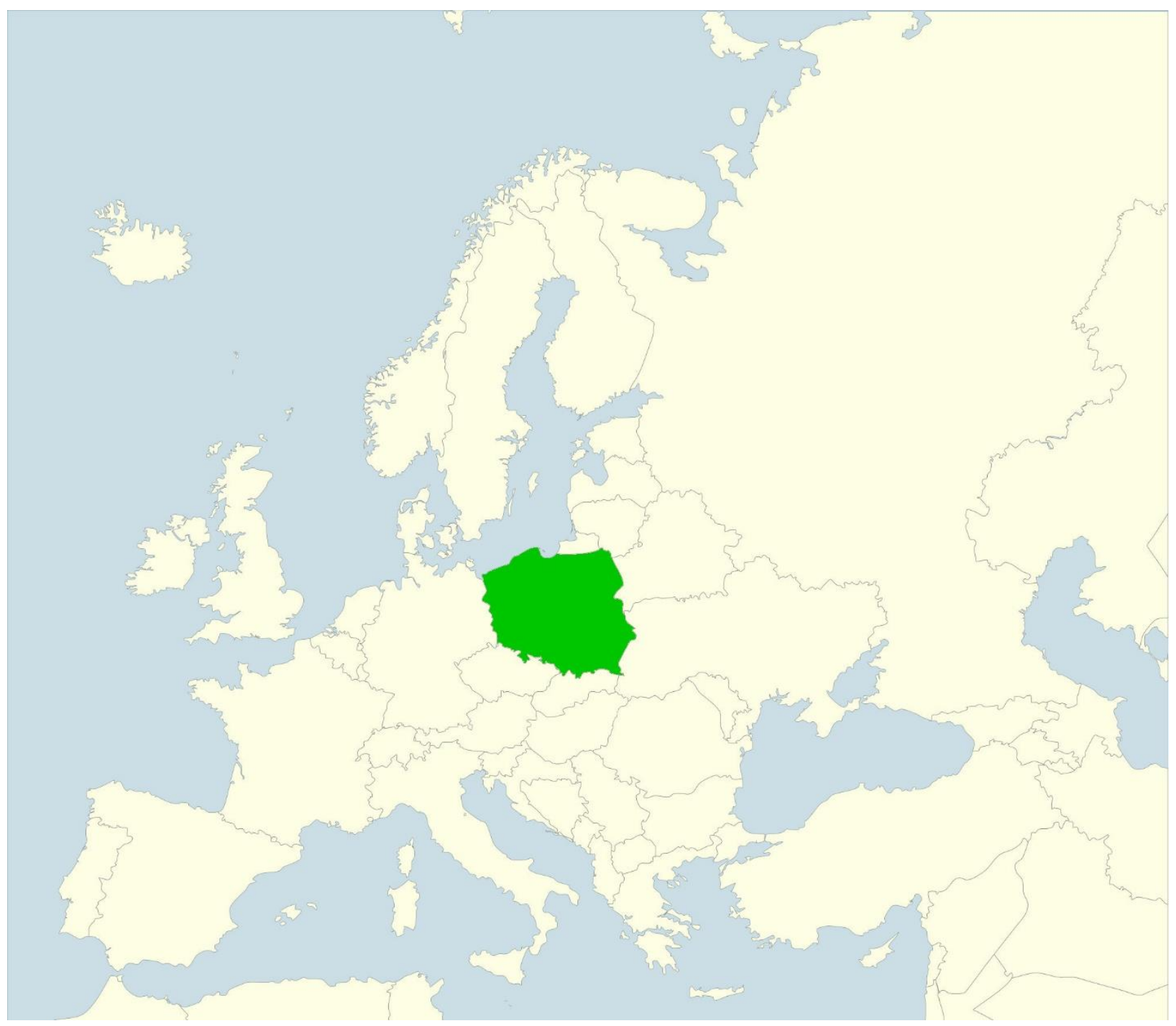

${ }^{1}$ Agata Ćwik, PhD, Department of Nature Conservation and Landscape Ecology, Institute of Agricultural Sciences, Land Management and Environmental Protection, College of Natural Sciences, University of Rzeszów, Poland, ORCID: 0000-0002-6197-9959, e-mail: acwik@ur.edu.pl (corresponding author)

2 Hanna Hrehorowicz-Gaber, PhD Arch., Department of Spatial Planning, Urban and Rural Design; Faculty of Architecture, Cracow University of Technology, Kraków, Poland, ORCID: 0000-0002-1567-6172, e-mail: hanna.hrehorowicz-gaber@pk.edu.pl 
Abstract: Mountainous rural areas are vulnerable to inappropriate land management, which is particularly visible in the Polish Carpathians. This paper attempts to diagnose the causes and effects of spatial chaos in this area, using the DPSIR method. The Three Questions method was used to assist in analysing the effects of disorder in the context of violating sustainable development. The analysis demonstrated that the causes of spatial disorder were mainly of legal and historical origins, with the most visible effects of this chaos being those related to the dispersion of buildings. Minimising spatial chaos requires extensive education, as well as amending legislation to limit the scope of decisions on development conditions. A national financial mechanism supporting the development of the Carpathians would also seem to be a desirable improvement.

Key words: Carpathian Convention, DPSIR, mountainous landscape, rural landscape, spatial chaos, spatial planning, 'Three Questions' method

Abstakt: Górskie obszary wiejskie są wrażliwe na niewłaściwe zagospodarowanie przestrzenne. Szczególnie mocno uwidacznia się ono w polskiej części Karpat. Podjęto zatem próbę diagnozy przyczyn i skutków chaosu przestrzennego w tym terenie, stosując metodę DPSIR. Oceniono także za pomocą metody Trzech Pytań skutki nieładu w kontekście naruszania przez nie idei rozwoju zrównoważonego. Przyczyny chaosu przestrzennego mają głównie naturę prawną, historyczną i ekonomiczną, natomiast skutki ujawniają się najbardziej poprzez rozproszenie zabudowy. Aby minimalizować chaos przestrzenny konieczne są przede wszystkim, oprócz szerokiej edukacji, zmiany w prawodawstwie, ograniczające planistyczną rolę decyzji o warunkach zabudowy. Pożądany wydaje się także krajowy mechanizm finansowy, wspierający Karpaty w rozwoju.

Słowa kluczowe: Konwencja Karpacka, DPSIR, krajobraz górski, krajobraz wiejski, chaos przestrzenny, planowanie przestrzenne, metoda "trzech pytań"

\section{Highlights}

- Causes of spatial disorder were mainly of legal and historical origins.

- Spatial chaos manifests itself mainly in the buildings' dispersion.

- Adverse spatial phenomena significantly hinder sustainable development.

- Limitation of the decisions on development conditions role is recommended.

- A financial mechanism supporting the development of the Carpathians is needed.

\section{Introduction}

For several decades, rural mountain areas in Central and Southern Europe have been experiencing profound changes related to the abandonment of arable lands, and the secondary plant succession that follows (MacDonald et al. 2000; Tasser et al. 2007; Kuemmerle 2008; Kozak 2010; Munteanu et al. 2017). Such changes affect the landscape, leading to a new balance established in the environment (García-Ruiz, Lana-Renault 2011; Wolski 2016; Ortyl et al. 2018). These processes are accompanied by social changes due to the ageing population, and the decrease in knowledge of traditional pastoral culture and its farming methods (O'Rourke 2019). Mountain areas achieve lower indicator values of socioeconomic development (Brańka 2015; Forleo et al. 2017). They are also usually more naturally valuable; traditional methods of land use favour the preservation of this biodiversity (Marini et al. 2009; Castro et al. 2010; Prince et al. 2012). However, in areas near mountain cities, uncontrolled suburbanisation often occurs (Węcławowicz-Bilska 2009), with residential and recreational functions being moved outside 
the city (Kowalczyk 1990). On the other hand, rural mountain areas located far from larger cities are exposed to marginalisation. In such areas, as in the Bieszczady Mts., it may take several hours to travel to an urban centre (GUS 2018) offering advanced services.

An exceptionally interesting European mountain region, the Carpathians, experience the phenomena described above. A diagnosis of the problems existing in this area led to the signing of the Carpathian Convention in 2003, aimed at stimulating the sustainable development of the lands covered by the convention. Although the ratification of the Convention does not automatically include any financing mechanisms, its framework provisions, after being implemented into national legislation, may contribute to minimising negative spatial phenomena occurring in the Carpathians. Most of them are not typical of mountain areas; they are found across the country, as follows from Śleszyński et al. (2018) detailed diagnosis of the causes of spatial disorder and recommendations for its minimisation, which were prepared for the whole of Poland. In the mountains, however, spatial chaos is particularly harmful because its effects are more severe there (Theissen et al. 2019) than in plains areas, where natural connections are less complex and the landscape is less attractive; both of which constitute to the basis for tourism development (Kistowski, Śleszyński 2010). Although the legal international instruments currently in force in Poland - including the Europe 2020 Strategy (European Commission 2010), the Carpathian Convention (CC 2003) and Polish law - Spatial Planning and Development Act (Ustawa 2003) - emphasise the need for sustainable development, the spatial chaos in the Polish Carpathians seems to significantly hinder this type of development. According to the Polish planning vision, sustainable development is complementary to spatial order (Ustawa 2003); the concept of sustainable development itself is multidimensional. The literature offers several hundred different definitions of this concept, developed and implemented into local and governmental strategies, especially after the 1992 Earth Summit in Rio de Janeiro (Munton, Collins 1998). All of these definitions share two elements. The first is the reference to intergenerational justice, similar to that presented in the Brundtland Report (WCED 1987). The second is sustainability, which specifically encompasses three dimensions: environmental, social and economic (Haughton, Counsell 2004; Venkatesh 2010). Some authors note that a fourth dimension, political, is also necessary (Munton, Collins 1998; Ekins 2000). Our study emphasises the second approach to sustainable development.

In the article, we (i) diagnose the causes and effects of spatial disorder in the Polish Carpathians, and (ii) evaluate these effects in terms of their incompatibility with the idea of sustainable development. This will lead to (iii) suggestions for ways to minimise the environmental negative phenomena.

\section{Methods}

\subsection{Study area}

The research was performed within the administrative boundaries of 200 Carpathian communes covered by the Carpathian Convention (CC 2003), located in the Silesian, Lesser Poland and Subcarpathian voivodeships (governorships) (Fig. 1), covering an area of $18,612 \mathrm{~km}^{2}$. Among them, 19 were urban communes while the others were rural and urban-rural. The four largest Carpathian cities are Krosno, Nowy Sącz, Nowy Targ and Przemyśl.

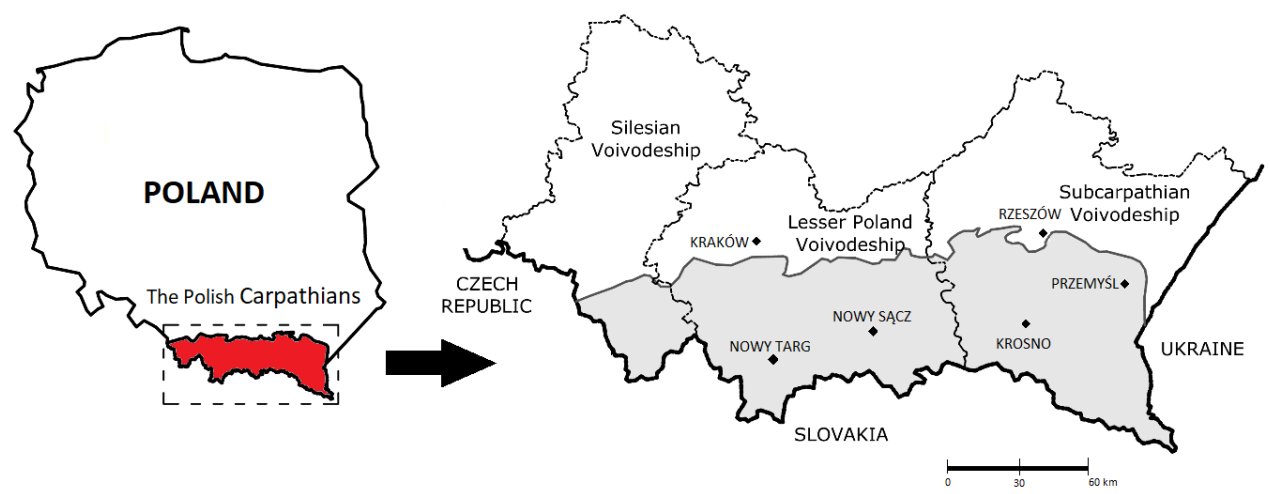

Fig 1. The study area. Source: own elaboration 
The Carpathians cover only $6.3 \%$ of Poland's total area (Solon et al. 2018). The highest point of the study area is located in the Tatra Mountains, where they reach a height of $2499 \mathrm{~m}$ above sea level. Their landscape is diverse: from the high-mountain range of the Tatra Mountains, through the mountain ranges of the Beskidy and Pieniny (Fig. 2), to the foothills and valleys. This diversity, the valuable natural environment conditioned by the peripheral location (Więckowski 2010), and the rich history of this region (where various cultures and ethnic groups met) create a significant touristic potential for this area. This is reflected in the high values of various tourism-related indicators, such as the development level of the tourism in the Polish border communes of the Carpathians (Durydiwka 2013), those of natural and cultural attractiveness, and those of the synthetic indicators of tourist attractiveness as cited by Durydiwka (2012). Agriculture plays a minor role in the functional structure of rural areas in the Polish Carpathians. There is intensive and commercial agricultural development only in a few communes; the remainder are predominantly residential, tourism, or recreation related, with the inclusion of agriculture and forestry (Bański, Stola 2002).

The western part of the study area is significantly more developed (Fig. 2). It scored the lowest indicator values of agricultural development, similarly to the Carpathian ranges at the southern part of the Lesser Poland voivodeship (Brańka 2015). The only areas that are not permanently inhabited are the higher parts of the Tatra Mountains and the interiors of national parks. Rural buildings in the Beskidy Mountains are concentrated in the river valleys, but the development is currently spreading to the higher slopes and ridges. This process leads to the problem of degradation of the cultural landscape, due to aggressive construction pressure. Numerous conflicts between people and the environment also concern the presence or vicinity of protected areas, as their network here is the most extensive in Poland, containing six national parks (Fig. 2) and 97 Natura 2002 sites within the study area.

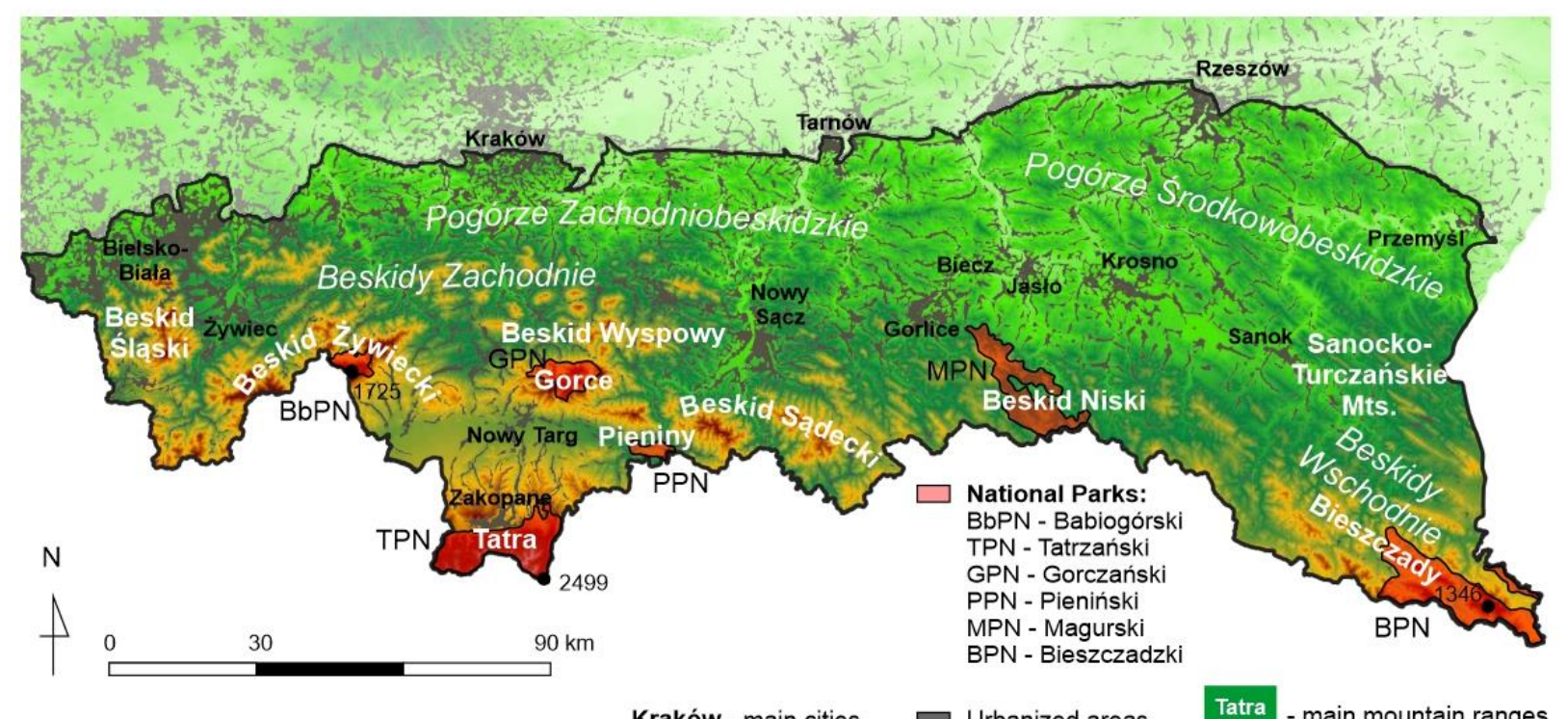

Fig 2. National parks and developed areas against main geographical regions indicated in the paper. Source: own elaboration (relief and settlement by Geoportal, national parks by Main Office of Geodesy and Cartography (GUGiK), borderline of the Carpathians adapted form Solon et al. 2018)

\subsection{The DPSIR framework}

When adapting the DPSIR method, we used an expert approach. We diagnosed the spatial chaos phenomenon through field observations during the last two decades, analysis of planning documents, and literature review. To summarise the phenomena defining spatial chaos and to understand their causes in order to try to define remedial actions, we used the interdisciplinary method Drivers Pressures State Impact Responses (DPSIR framework) (EEA 1995, HoltenAndersen et al. 1995; UNEP 2002; OECD 2003; Svarstad et al. 2008). Although this method is mainly used to diagnose negative phenomena occurring in the natural environment (Maxim et al. 
2009; Gari et al. 2015; Pullanikkatil et al. 2016; Spanò et al. 2017), we decided that it was both broad and coherent enough to also apply to studying non-natural phenomena related to spatial chaos. In our research, we used the following understanding of the method's parameters (Fig. 3): "drivers" (D) as the causes of spatial disorder, "pressures" $(P)$ as a type of negative human influence on space, "state" (S) as a specific manifestation of a phenomenon, "impact" (I) as the economic, social or environmental impact of an event, and "responses" (R) as possible actions that could be taken to minimise the effects of spatial chaos.

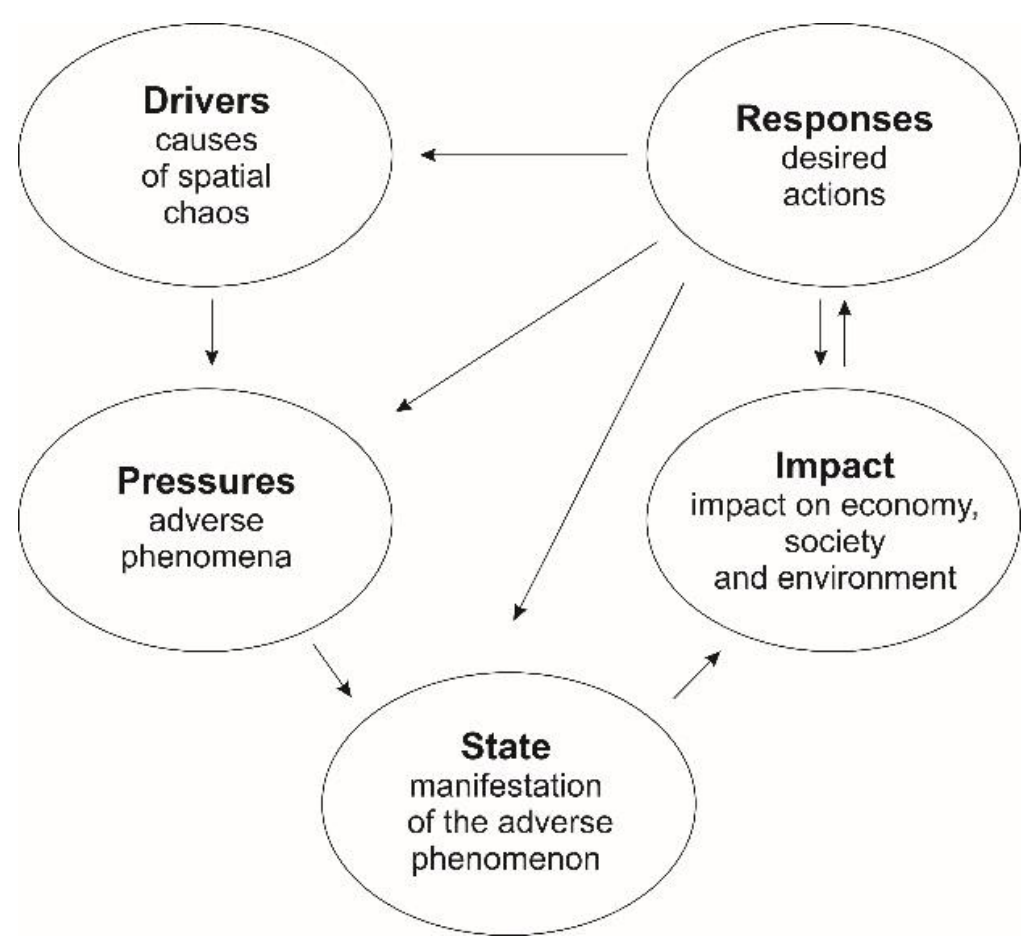

Fig 3. The DPSIR framework adjusted to the investigation procedure. Source: own elaboration (the DPSIR model adapted from Smeets and Weterings 1999)

\subsection{Diagnosis of compliance of spatial phenomena with the idea of sustainable development}

We referred to the "impact" (I) category as consisting of three main dimensions of sustainable development: economic (Ec), social (Sc) and environmental (En). Consistent with the assumption of the "Three Questions" method (Ćwik 2014), we decided that if a given phenomenon violates any of these three dimensions, the space in which it occurs does not develop in a sustainable manner. This diagnosis is based on answers to three questions: (1) Does a given phenomenon in space have excessive adverse effects on the functioning of the natural environment (the En dimension)? (2) Is this phenomenon socially acceptable, and does it serve the society (Sc)? (3) Is it economically profitable in the long-term time perspective (Ec)?

To answer these questions, we used an expert method. If the answer to any of these questions was negative, we marked this fact in the results table (Tab. 1) in red (Ec), yellow (Sc) or green (En). The greatest discrepancy with the assumptions of sustainable development concerned the phenomena that violated all of the three basic dimensions. An intermediate situation occurred when one or two dimensions were violated. As the aim of the work was to diagnose negative phenomena causing spatial chaos, none of these phenomena were expected to be fully consistent with the idea of sustainable development. 


\section{Results and discussion}

\subsection{Symptoms of spatial chaos and their causes (drivers, pressures and state)}

The causes of spatial chaos in the Polish Carpathians are of an historical, legal, economic and social nature; some are related to various spatial and environmental conditions. The most important causes, however, are legal conditions. Although the need to address spatial order and sustainable development is included in Polish legislation, the detailed solutions of the Act (Ustawa 2003), unfortunately, are not sufficient to protect land against degradation. Also contributing to the difficulty is the extensive legal environment of the spatial planning system, consisting of several other acts and regulations. Spatial development plans for voivodeships are largely general, adopted at different times, and have provisions written in various forms. No methods have been developed to transfer the provisions of higher-order plans into local planning documents, thereby hindering the coordination of planning studies in three voivodeships of the Carpathian region. Planning strategies, which constitute the basis of development processes in communes, include studies of the conditions and directions of spatial development (the study) to determine the long-term direction of development, and constitute the spatial policy of the commune. As well, local spatial development plans (a local plan) constitute local law.

The planning situation of the studied area is very diverse. Silesian and partly Lesser Poland communes have local plans for most of their areas, but there are hardly any such communes in the Subcarpathian voivodeship (Gibas, Heffner 2018). The Act on Spatial Planning and Development (Ustawa 2003) allows the development of "point plans", meaning that a space is not treated as a coherent whole. Another factor behind the chaos visible in the landscape is the defective spatial policy of communes. Such policy is often short-sighted, focusing on keeping residents or attracting investors; an approach likely related to the term of office of the authorities and the shortcomings of their spatial and economic education. The most onerous phenomena, resulting mainly from the spatial planning system, are the scattering of buildings in rural areas and urban sprawl in suburban areas (Tab. 1).

Tab 1. Causes and effects of the spatial chaos in terms of the DPSIR framework. Source: own elaboration

\begin{tabular}{|c|c|c|c|c|c|c|}
\hline \multirow{2}{*}{ Drivers } & \multirow{2}{*}{ Pressures } & \multirow{2}{*}{ State } & \multicolumn{3}{|c|}{ Impact } & \multirow[t]{2}{*}{ Responses } \\
\hline & & & Ec & Sc & En & \\
\hline \multirow{4}{*}{ historical } & \multirow{4}{*}{$\begin{array}{l}\text { SMALL SIZE OF } \\
\text { PLOTS AND THEIR } \\
\text { FRAGMENTATION }\end{array}$} & $\begin{array}{l}\text { lack of profitability of } \\
\text { agricultural production }\end{array}$ & & & & \multirow{4}{*}{$\begin{array}{l}\text { introduction of a land } \\
\text { consolidation } \\
\text { financing program at } \\
\text { the powiat (county) } \\
\text { level; } \\
\text { appropriate provisions } \\
\text { of local plans to } \\
\text { specify the size of } \\
\text { the plot }\end{array}$} \\
\hline & & $\begin{array}{l}\text { increased drainage of } \\
\text { slopes through access } \\
\text { roads to fields }\end{array}$ & & & & \\
\hline & & $\begin{array}{l}\text { breaking ecological } \\
\text { connections }\end{array}$ & & & & \\
\hline & & $\begin{array}{l}\text { fief settlement (plots of } \\
\text { land in the form of long } \\
\text { narrow strips) }\end{array}$ & & & & \\
\hline $\begin{array}{l}\text { historical } \\
\text { legal } \\
\text { social }\end{array}$ & $\begin{array}{l}\text { STEEP SLOPES } \\
\text { AND SPRING } \\
\text { NICHES } \\
\text { OVERLOADED } \\
\text { WITH BUILDINGS }\end{array}$ & $\begin{array}{l}\text { landslides and other } \\
\text { intensive } \\
\text { geomorphological } \\
\text { processes }\end{array}$ & & & & $\begin{array}{l}\text { addressing } \\
\text { the timeliness and } \\
\text { quality of eco- } \\
\text { physiographic studies } \\
\text { in communes; } \\
\text { introducing } \\
\text { permissions to create } \\
\text { eco-physiographic } \\
\text { studies }\end{array}$ \\
\hline $\begin{array}{l}\text { economic } \\
\text { legal }\end{array}$ & $\begin{array}{l}\text { UNDERCUTTING } \\
\text { OF SLOPES BY }\end{array}$ & $\begin{array}{l}\text { landslides and other } \\
\text { ground movements }\end{array}$ & & & & $\begin{array}{l}\text { addressing of the } \\
\text { timeliness and quality }\end{array}$ \\
\hline
\end{tabular}




\begin{tabular}{|c|c|c|c|}
\hline \multirow[t]{2}{*}{ spatial } & \multirow{2}{*}{$\begin{array}{l}\text { THE TRANSPORT } \\
\text { NETWORKS AND } \\
\text { ASSOCIATED } \\
\text { DEFORESTATION }\end{array}$} & $\begin{array}{l}\text { break in ecological } \\
\text { connections }\end{array}$ & \multirow{2}{*}{$\begin{array}{l}\text { of eco-physiographic } \\
\text { studies in communes; } \\
\text { economic analysis of } \\
\text { the viability of the } \\
\text { investment location }\end{array}$} \\
\hline & & $\begin{array}{l}\text { increased investment } \\
\text { to maintain the } \\
\text { transport network }\end{array}$ & \\
\hline \multirow{5}{*}{$\begin{array}{l}\text { historical } \\
\text { legal } \\
\text { social }\end{array}$} & \multirow{5}{*}{$\begin{array}{l}\text { SCATTERED } \\
\text { BUILDINGS }\end{array}$} & $\begin{array}{l}\text { increased expenditures } \\
\text { on infrastructure and } \\
\text { commuting }\end{array}$ & \multirow{5}{*}{$\begin{array}{l}\text { education aimed at } \\
\text { communes and } \\
\text { residents on } \\
\text { economic, social and } \\
\text { environmental costs; } \\
\text { legal changes - } \\
\text { the need for decisions } \\
\text { on building conditions } \\
\text { to comply with } \\
\text { the commune's spatial } \\
\text { policy (a study of } \\
\text { the conditions and } \\
\text { directions of spatial } \\
\text { development) }\end{array}$} \\
\hline & & $\begin{array}{l}\text { weakening of family } \\
\text { and neighbour ties }\end{array}$ & \\
\hline & & $\begin{array}{l}\text { loss of areas for } \\
\text { transhumance } \\
\text { shepherding }\end{array}$ & \\
\hline & & $\begin{array}{l}\text { reduction of water } \\
\text { retention }\end{array}$ & \\
\hline & & $\begin{array}{l}\text { breaking of ecological } \\
\text { connections }\end{array}$ & \\
\hline \multirow{8}{*}{$\begin{array}{l}\text { economic } \\
\text { legal } \\
\text { social }\end{array}$} & \multirow{8}{*}{ URBAN SPRAWL } & $\begin{array}{l}\text { increased expenditures } \\
\text { on infrastructure and } \\
\text { commuting }\end{array}$ & \multirow{8}{*}{$\begin{array}{l}\text { determining } \\
\text { the reliability and } \\
\text { scientific basis of } \\
\text { the balance of } \\
\text { the land for } \\
\text { development, from } \\
\text { a study of } \\
\text { the conditions and } \\
\text { directions of spatial } \\
\text { development; } \\
\text { protection of } \\
\text { the natural system of } \\
\text { cities and their } \\
\text { surroundings through } \\
\text { local spatial } \\
\text { development plans }\end{array}$} \\
\hline & & $\begin{array}{l}\text { weakening of family } \\
\text { and neighbour ties }\end{array}$ & \\
\hline & & $\begin{array}{l}\text { reduction of water } \\
\text { retention }\end{array}$ & \\
\hline & & $\begin{array}{l}\text { breaking of ecological } \\
\text { connections }\end{array}$ & \\
\hline & & $\begin{array}{l}\text { decline in the value of } \\
\text { landscape quality }\end{array}$ & \\
\hline & & $\begin{array}{l}\text { reduction of landscape } \\
\text { visual virtues }\end{array}$ & \\
\hline & & $\begin{array}{l}\text { loss of the city's } \\
\text { ecological buffer zone }\end{array}$ & \\
\hline & & $\begin{array}{l}\text { loss of agrocenoses } \\
\text { and open areas } \\
\text { conducive to animal } \\
\text { migration }\end{array}$ & \\
\hline $\begin{array}{l}\text { historical } \\
\text { legal } \\
\text { social }\end{array}$ & STYLISTIC CHAOS & architectural disorder & $\begin{array}{l}\text { education to shape } \\
\text { a sense of aesthetics }\end{array}$ \\
\hline $\begin{array}{l}\text { historical } \\
\text { legal } \\
\text { social }\end{array}$ & $\begin{array}{l}\text { DISAPPEARANCE } \\
\text { OF THE } \\
\text { INDIGENOUS } \\
\text { STYLES OF } \\
\text { BUILDINGS }\end{array}$ & $\begin{array}{l}\text { decline in the value of } \\
\text { landscape quality }\end{array}$ & $\begin{array}{l}\text { developing catalogues } \\
\text { of permissible } \\
\text { architectural forms, as } \\
\text { attachments to } \\
\text { planning documents; } \\
\text { developing a financial } \\
\text { policy of the commune } \\
\text { that promotes local } \\
\text { architecture }\end{array}$ \\
\hline \multirow{2}{*}{$\begin{array}{l}\text { historical } \\
\text { legal } \\
\text { spatial } \\
\text { social }\end{array}$} & \multirow{2}{*}{$\begin{array}{l}\text { CHANGES OF } \\
\text { AGRICULTURAL } \\
\text { LANDS INTO } \\
\text { SETTLEMENTS ON }\end{array}$} & $\begin{array}{l}\text { loss of valuable areas } \\
\text { for tourism }\end{array}$ & \multirow{2}{*}{$\begin{array}{l}\text { introducing landscape } \\
\text { studies to the planning } \\
\text { process }\end{array}$} \\
\hline & & $\begin{array}{l}\text { reduction of landscape } \\
\text { visual virtues }\end{array}$ & \\
\hline
\end{tabular}




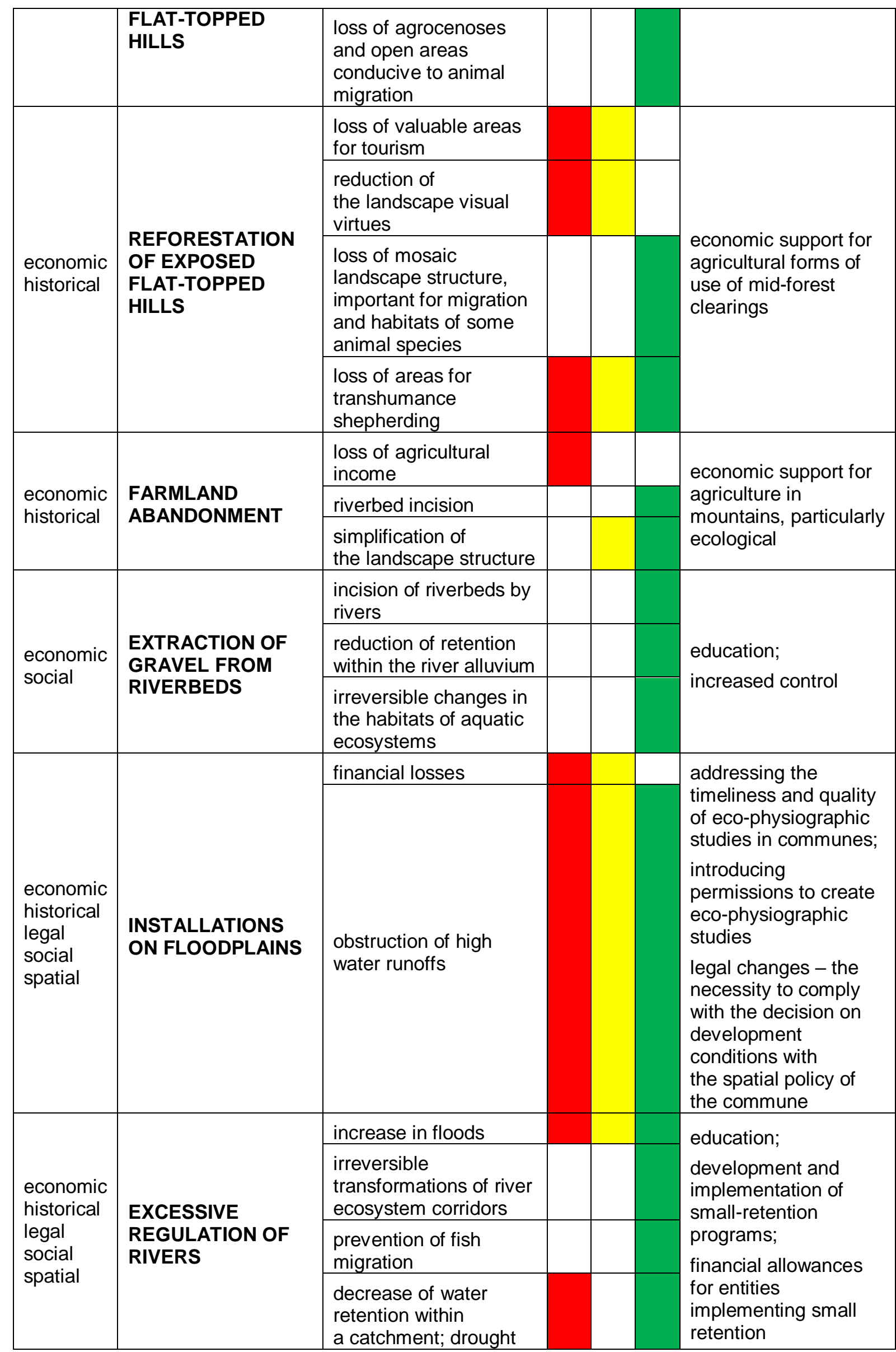




\begin{tabular}{|c|c|c|c|}
\hline & & $\begin{array}{l}\text { financial losses in } \\
\text { the event of } \\
\text { catastrophic floods }\end{array}$ & \\
\hline \multirow{3}{*}{$\begin{array}{l}\text { economic } \\
\text { social }\end{array}$} & \multirow{3}{*}{$\begin{array}{l}\text { MASS TOURISM } \\
\text { ROUTES }\end{array}$} & $\begin{array}{l}\text { increased } \\
\text { geomorphological } \\
\text { processes }\end{array}$ & \multirow{3}{*}{$\begin{array}{l}\text { developing strategies } \\
\text { aimed at } \\
\text { implementing } \\
\text { the provisions of } \\
\text { the Carpathian } \\
\text { Convention on } \\
\text { redirecting tourist } \\
\text { traffic from } \\
\text { overpopulated places }\end{array}$} \\
\hline & & $\begin{array}{l}\text { destruction of } \\
\text { vegetation and animal } \\
\text { habitats }\end{array}$ & \\
\hline & & $\begin{array}{l}\text { decreased landscape } \\
\text { quality }\end{array}$ & \\
\hline \multirow{8}{*}{$\begin{array}{l}\text { economic } \\
\text { social } \\
\text { spatial }\end{array}$} & \multirow{8}{*}{$\begin{array}{l}\text { SKI SLOPES IN } \\
\text { VALUABLE } \\
\text { NATURAL AREAS }\end{array}$} & spatial conflicts & \multirow{8}{*}{$\begin{array}{l}\text { education; } \\
\text { promoting alternative } \\
\text { forms of sports and } \\
\text { skiing tourism (ski- } \\
\text { touring, cross-country } \\
\text { skiing); } \\
\text { conducting a planning } \\
\text { process in } \\
\text { the commune } \\
\text { independently of } \\
\text { the investor }\end{array}$} \\
\hline & & $\begin{array}{l}\text { breaking of ecological } \\
\text { connections }\end{array}$ & \\
\hline & & $\begin{array}{l}\text { increased } \\
\text { geomorphological } \\
\text { processes }\end{array}$ & \\
\hline & & excessive soil erosion & \\
\hline & & $\begin{array}{l}\text { changes in plant } \\
\text { communities }\end{array}$ & \\
\hline & & $\begin{array}{l}\text { faster runoff, decrease } \\
\text { in retention }\end{array}$ & \\
\hline & & $\begin{array}{l}\text { adverse changes in } \\
\text { the landscape }\end{array}$ & \\
\hline & & $\begin{array}{l}\text { noise pollution - impact } \\
\text { on animal populations }\end{array}$ & \\
\hline
\end{tabular}

Not only are cities such as Rzeszów (198,000 inhabitants) and Tarnów $(109,000)$ located on the border of the studied area experiencing faster urbanisation, but also medium-sized Carpathian cities such as Nowy Sącz $(83,000)$, and even smaller towns such as Nowy Targ $(33,000)$. Ćwik and Ortyl (2016) showed that the dispersion of buildings in the mountainous suburbs of Rzeszów was greater than that in mountainous foothills in the vicinity of this city. The latest research by Serafin (2017) showed that the suburban area around Nowy Sącz was also urbanising. There is an extremely intense dispersion of buildings on the slopes of the western part of the Beskid Niski Mountains and on the slopes of the Beskid Wyspowy Mountains (Fig. 2, Fig. 4a). A factor that triggers and then sanctions these phenomena are decisions on building conditions, which are issued without a broader context. Prepared in the absence of a local plan, they do not have to be consistent with the commune's spatial policy (the study). Shaping spatial development using this tool takes place mainly in the Subcarpathian part of the studied area (Śleszyński 2012). The development of local plans is optional and sometimes also inconvenient for the commune authorities, as it limits investment freedom. If plans do already exist, they often reserve land for development that is disproportionate to the actual needs. According to Śleszyński (2015), $25 \%$ of the communes of the area he studied reserved over $50 \%$ of their area for development in their planning documents (as of 2013), not including forests and waters. Such an approach leads to the scattering of buildings and to the phenomenon of urban sprawl, thus translating to increased expenditure on infrastructure, increased travel time to schools and work, the breaking of neighbourly ties (Kowalewski et al. 2013), the degradation of the landscape, and breaking of natural connections (Tab. 1). Shaping the spatial development in line with the commune's spatial policy adopted in the Study also does not protect these areas from degradation. Detailed analyses of planning documents carried out for the Carpathian commune of Biecz by Ciepiela and Łasocha (2020) are significant. They showed that despite the population decline between 2003 and 2017, for which subsequent studies were prepared, the areas assigned for development in these documents increased several times. This created the risk of building dispersion, somehow sanctioned by law. Śleszyński et al. $(2018,2020)$ estimated that the costs 
of building dispersion in the communes of the Beskid Niski Mts. and the Bieszczady Mts. were among the highest in the country, amounting to over 5,000 PLN per capita.

Legal reasons that trigger phenomena influencing spatial chaos also include the deregulation of the town planner role, and a lack of authorised requirements to create eco-physiographic studies. Such studies constitute a comprehensive analysis of the environmental conditions of spatial development, which are necessary to make appropriate planning decisions. Quality control of eco-physiographic studies for selected Carpathian communes (Karpacka Przestrzeń 2019) showed that the quality of these documents was far from satisfactory, were not based on field studies, and contained many factual errors. Such studies led to poor planning decisions related to the location of buildings or infrastructure; for example, roads interfered with the course of ecological corridors, and development was allowed in areas with outstanding scenic values or in areas with natural barriers, such as excessively steep slopes. They also allowed downhill skiing routes in locations causing spatial conflicts, especially those with a protective function. Other mistakes included provisions proposing deforestation of mid-forest clearings, thereby limiting the touristic potential of these areas and simplifying the landscape structure, which may limit the range of habitats of animals preferring a mosaic landscape. Brunori et al. (2016) showed that an open agricultural landscape without scattered development favours proper functioning of ecological networks. Development of mountainous slopes and undercutting of this area by transport networks, are among the causes of triggering landslide processes (Fig. 4b). Senetra et al. (2014) reported that from 2007-2013, in all mountainous parts of the Podkarpackie voivodeship, urbanised areas and areas covered by transport networks increased. Not only are the Beskidy Wschodnie Mountains exposed to landslides, but also other parts of the Carpathians, which comprise as much as $95 \%$ of all landslides occurring in Poland. Their density is over one landslide per $\mathrm{km}^{2}$, and over $7 \%$ of them have anthropogenic origins (Rączkowski 2007). Such a situation calls for caution in making location decisions, which should be based on reliable knowledge about how the environment functions - knowledge that should be provided by an ecophysiographic study. Scattered building and urban sprawl (Fig. 4c) also result from historical processes that have been shaping urban structures, thereby having their roots in spatial management.

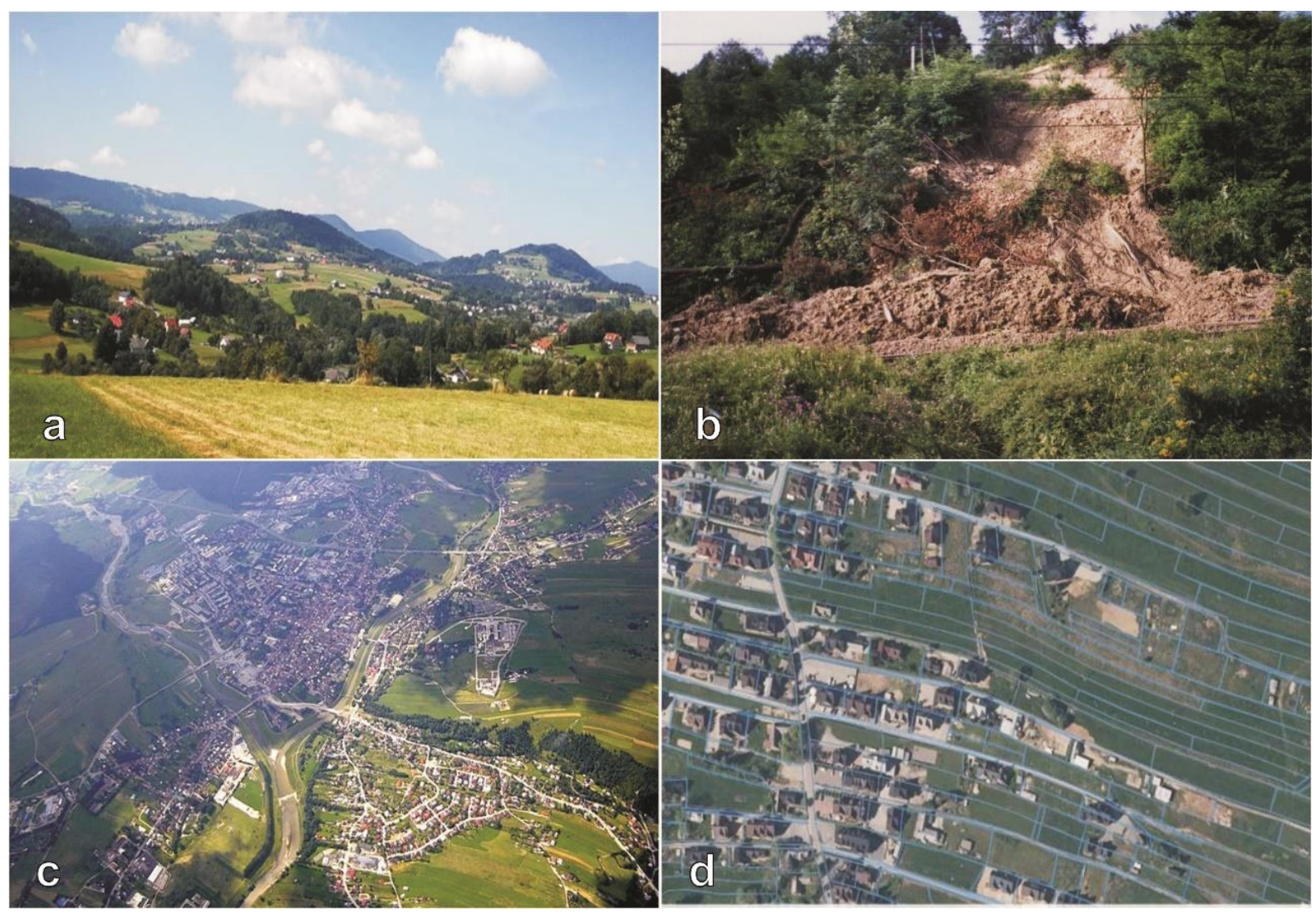

Fig 4. Types of pressure increasing spatial chaos in the Polish Carpathians. 
a - dispersed building development in the Beskid Wyspowy Mountains (photo by H. Hrehorowicz-Gaber)

$b$ - a railway line that cuts the slope and triggers a landslide in the Beskid Niski Mountains (photo by A. Ćwik)

$c$ - urban sprawl in Nowy Targ (Podhale) (wikipedia.pl)

$d-$ a field layout of land plots with secondary divisions in Podhale (geoportal.gov.pl)

In the Polish Carpathians, historical and economic processes led to ownership fragmentation of farms on a wide scale. According to the 2016 census data of the Central Statistical Office of Poland, the average farm size in Poland was 10.3 ha; in other countries covered by the Carpathian Convention in 2017, the average farm sizes were 77.5 ha in Slovakia, 152.4 ha in Czechia, 19.2 ha in Austria, 3.5 ha in Romania, 8.1 ha in Hungary, 5.1 ha in Ukraine, and 3.5 ha in Serbia (Hrehorowicz-Gaber 2019). In the south of Poland, however, in the mountain and foothill areas, the average farm was about 3.3 ha. This situation results from the historical structure of agricultural lands, the so-called "fief field system". This system is partially based on a structure primarily used as early as the Middle Ages, with fields being directed from mountain ridges to valley bottoms; this system later underwent fragmentation due to secondary divisions (Hrehorowicz-Gaber 2019). The above-mentioned field structures (Fig. 4d) have been preserved in the landscape to this day, with the buildings located within them being concentrated closer to the valley bottom. Sometimes buildings directly represent this structure, creating narrow stripes surrounded by open areas (fief buildings). Even the smallest farms are very rarely found in one piece, a consequence of historic agricultural reforms and legislative inefficiencies related to consolidation and re-parcelling of land. Due to the large amount of fragmentation, land plots require access roads. These are usually unpaved roads which accelerate surface runoff, thus lowering water retention and draining large amounts of mineral material from the slopes. They also transform over time into deep hollow paths (Fig. 5a). Field observations indicate that even paved roads transport water and mineral material down the slope (Fig. 5b). Studies from the central part of the Polish Carpathians (Beskid Sąecki) indicated that access roads are the main source of mineral material transported by rivers (Froehlich, Walling 1997). Today in the Polish Carpathians, these phenomena are more frequently seen in forest areas, where timber skidding is carried out (Affek et al. 2019), than agricultural areas, where dirt roads tend to become overgrown (Kroczak et al. 2016). One of the unfavourable effects of these phenomena may be the increased intensity of flash floods (Affek 2019). As reported by numerous authors (e.g., Kozak 2010; Munteanu et al. 2015) and confirmed in this research, agricultural areas have been increasingly abandoned and as a result, overgrown (Fig. 5c), very likely due to the lack of profitability of production in these areas.

At the turn of the twentieth century, the Carpathian population of various nationalities from the area then known as Galicia, migrated intensively "in search of bread," especially to the United States (Pollack 2011). Due to a high birth-rate, however, the areas of the Polish Carpathians were still intensively used for agriculture. It was only during World War II and immediately after that (1947) the central and eastern parts of Beskidy Mountains (Beskid Niski, Sanocko-Turczańskie Mts. and Bieszczady, Fig. 2) experienced deep depopulation related to the displacement of the Rusyn population (Trzeszczyńska 2015), still a unique phenomenon in Europe at that time (Soja 2008). Detailed research by Bański and Wesołowska (2020) on depopulation of rural areas conducted for the years 1950-2011 showed a clear spatial duality of this phenomenon in the Polish Carpathians. Most of the villages in the foothills (Pogórze Zachodniobeskidzkie and Środkowobeskidzkie, Fig. 2) are characterised by a population decline, even over $50 \%$ in some. In contrast, the areas to the south, perhaps due to a more developed tourist function, are characterised by an increase in the number of inhabitants. Even a two-fold increase in the number of people during this period was recorded, especially around cities such as Nowy Sącz and Sanok (Fig. 2). From 2006 to 2008, the region faced the greatest outflow of rural population to cities, which took place in their eastern areas: Beskidy Wschodnie Mountains and the Przemyśl Foothills, and in the border commune of Szczawnica (Rosner 2016). 


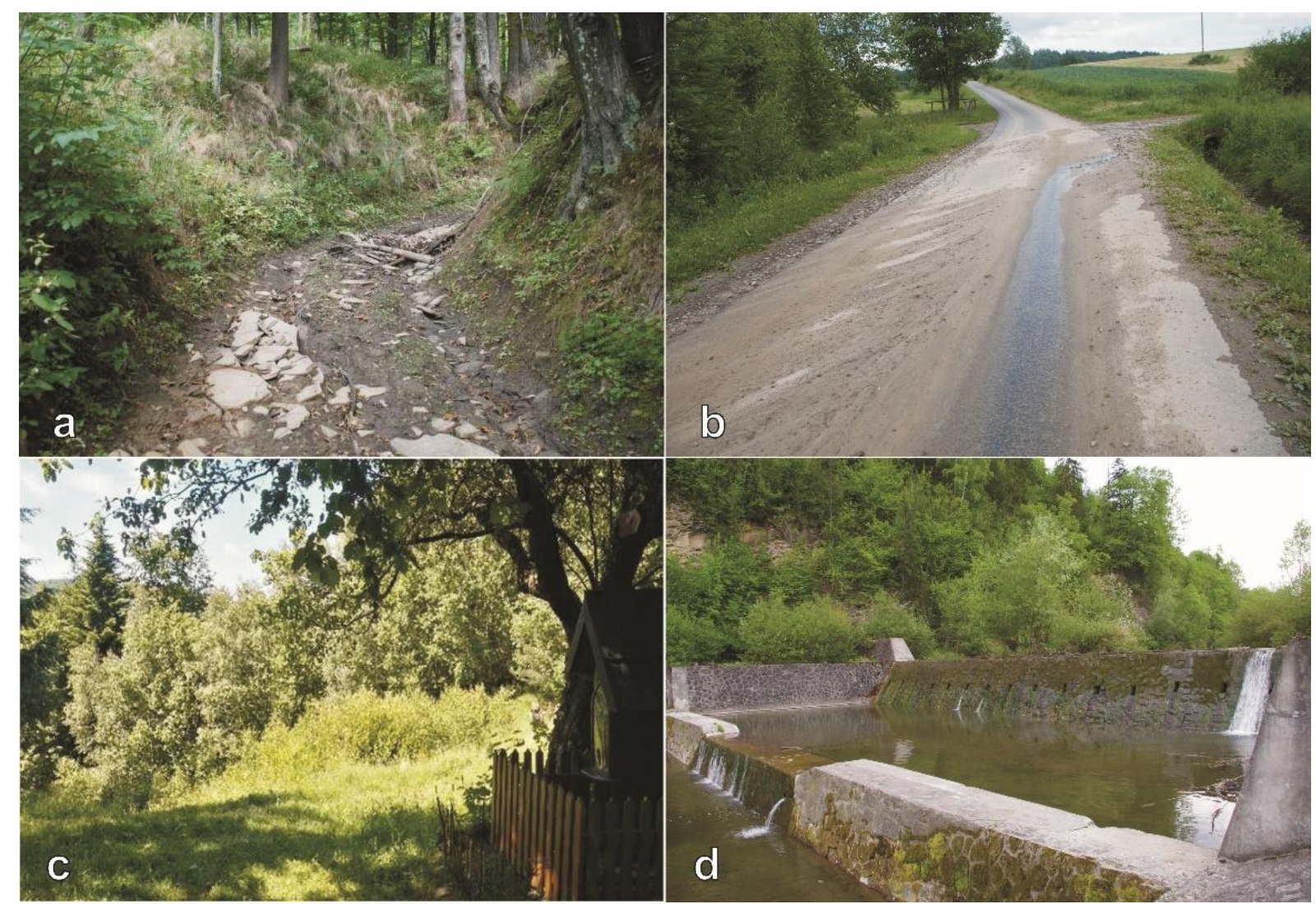

Fig 5. Pressure symptoms interfering with the functioning of the natural environment.

a - slopes cut by access roads to fields and forests in Beskid Niski (photo by A. Ćwik)

$b$ - mineral material flowing from dirt roads in Beskidy Wschodnie (photo by A. Ćwik)

c - overgrown abandoned field in Beskid Sądecki (photo by H. Hrehorowicz-Gaber)

$d$ - the regulated bed of the Porębianka stream in the Beskid Wyspowy (photo by K. Kukuła)

The abandonment of cultivated fields significantly changes the natural environment's function, especially in a hydrological aspect (Bystřický et al. 2017). This leads to faster runoff, resulting in riverbed incision (Wyżga et al. 2012), changes in aquatic ecosystems, and the shaping of a new environmental balance. Over-regulation of rivers and the extraction of river gravel led to the lowering of river beds (Rinaldi et al. 2005; Zawiejska et al. 2015). In the Polish Carpathians, this over-regulation sometimes takes drastic forms, such as concrete troughs with obstacles preventing fish migration (Plesiński et al. 2018; Fig. 5d); it also changes the habitats of aquatic fauna (Bylak et al. 2009). The bottoms of the Carpathian valleys experience the strongest spatial conflicts, a consequence of the lack of land available for investments (Ćwik 2013). These areas are also characterised by high air pollution, which decreases their touristic attractiveness in the winter season (Fig. 6a). Spatial chaos in valleys is caused not only by the improper proximity of functions such as industrial and residential buildings, and environmental conditions such as smog, but most significantly by building development in floodplain terraces.

Historical causes behind spatial chaos are closely related not only to spatial and environmental conditions, but also to social changes occurring in mountainous rural areas. Previously, villages constituted the dominant urban structures in the area, inhabited mainly by peasants. The situation changed relatively recently, when infrastructural and social conditions began to allow an existence more similar to that in the city (due to improved technical and communication infrastructure, access to schools, and the Internet). The incoming population (mostly urban) settling new rural areas in the last 25 years, has not been related to the local community. Therefore, the newcomers chose isolated areas, often of significant sightseeing value, e.g., on plateaus or mountain ridges (Fig. 6b). This is also accompanied by the phenomenon of the second homes with a recreational function. Mika and Faracik (2008) estimate that there are about 15,000 such buildings in the Polish Carpathians, located mainly in Beskidy Zachodnie. It does not seem that this 
phenomenon may be related to the counter-urbanisation of Carpathian cities, as the owners come mainly from outside the Carpathians (Mika, Faracik 2008). However, the phenomenon of second homes itself may contribute to counter-urbanisation (Halfacree 2012). Nevertheless, the factors described above, in addition to settlement development (on farmers' agricultural lands), are causing a severe scattering of buildings and a great loss of areas valuable for tourism.
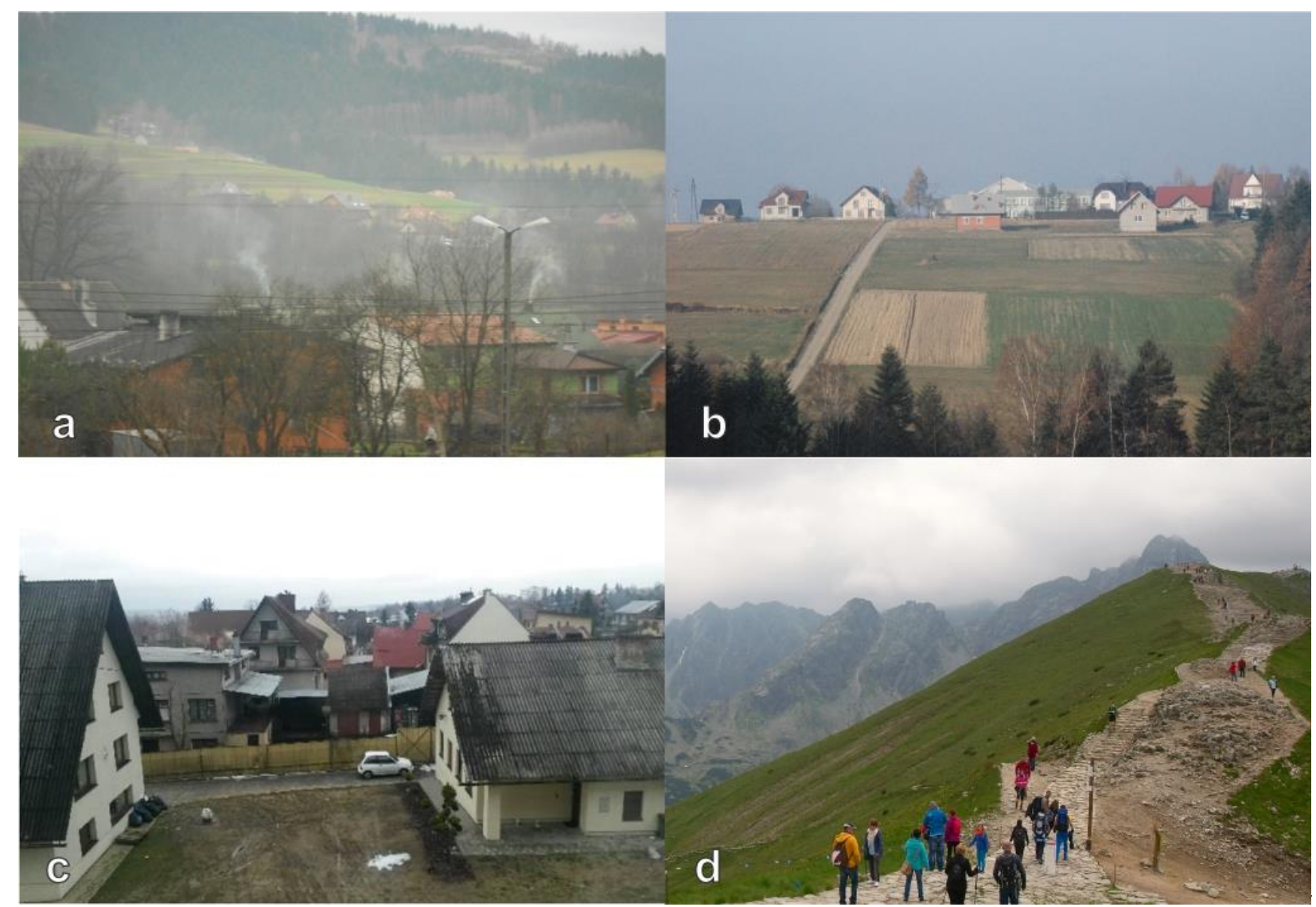

Fig 6. Symptoms of architectonic and functional chaos.

a - colour disorder in a mountain valley polluted with coal smoke in the Beskid Niski Mountains (photo by A. Ćwik)

$b$ - development on plateaus in the suburban area of Nowy Sącz (photo by A. Ćwik)

c - chaos of architectural styles: a cacophony of forms in Nowy Targ (photo by H. Hrehorowicz-Gaber)

$d$ - overloaded and destroyed tourist trail in the Tatra Mountains on the border of Poland and Slovakia (photo by G. Wiśniewski)

Carpathian cities are affected by other processes. The first urban centres served mainly defensive and commercial functions. The Magdeburg law allowed the inhabitants and the founders of towns (e.g., Biecz, Nowy Sącz) to take advantage of numerous privileges. Over time, these functions changed, giving way to services and crafts, and later (up to the present day) to culture, education, entertainment and administration. Poland's accession to the European Union (2004) opened the possibility of financing various types of economic, social and infrastructural activities, triggering yet another economic boom. Once again, cities became the centres of growth, and the surrounding areas were urbanised to create larger and larger suburbs. As a result, migration of the urban population to suburban areas around Carpathian cities between 2006 and 2008 reached the highest rates in the country: over 10 people per 1,000 inhabitants. This phenomenon was apparent in the greatest number of communes around Bielsko Biała and Kraków, but also Tarnów, Rzeszów, Przemyśl, Sanok, Nowy Sącz, and even Gorlice (Fig. 2). Apart from suburban areas, the phenomenon occurred in the Cisna commune in the Bieszczady Mts. (Rosner 2016), perhaps because the areas in the vicinity of the national park are attractive for migration due to the possibility of developing tourism (Zawilińska 2020). Suburbs are becoming an inseparable element of the landscape in the shadow of large cities, a transitional area to historically created settlement units (i.e., villages) absorbing them or blurring their distinctiveness. This has led to 
the urbanising of rural and urban structures, which interfere with the recreational and environmental functions of the outer part of the city's natural system (green belts) (Cieszewska 2019). Among the reasons behind the progressive degradation of the landscape should be included the low level of environmental awareness of local communities, manifesting itself in their poor participation in consultations of developing planning documents; participation often includes only the people whose properties may be affected by a given planning solution. Combined with the changes in the values professed by society in connection with political transformation, this low awareness has also influenced the deepening of architectural chaos in the landscape (Śleszyński et al. 2018). Contemporary communities inhabiting mountains seem not to treat space as a common and yet exhaustible resource. This leads to a frequent desire to shape the appearance of houses or properties so that they stand apart from the neighbouring buildings, resulting in the disappearance of native styles of development (Fig. 6c), with each house looking different from others. This phenomenon overlaps with extensive outdoor advertising along communication routes and in tourist centres such as Podhale, and is implicitly sanctioned by social indifference. Listwan-Franczak and Franczak (2015) indicated significant differences between advertising clutter along the main communication routes on the Polish and Slovakian sides of the Tatra Mountains. Up to 90 advertisements per kilometre of road were recorded in Poland, compared to less than 20 per kilometre in Slovakia. The authors explained this observation with greater car traffic and a more developed tourist function in the Polish part of the Tatra Mountains.

To better understand the reasons behind the process of architectural disorder in Poland, we must first examine the time before the political transformation of the 1990s. Economic and political transformations in Poland were strongly reflected in the land during the first post-war phase - first as a result of land consolidation, expropriation and the displacement of the population; then later as a result of a poorly-coordinated command-and-distribution economy, and the unification of architectural styles unrelated to the native landscape (e.g., construction of "block houses" in the 1970s). Many aberrations visible in the Polish Carpathian land space resulted from the economic system of privately-built houses (i.e., construction by owner or by owner-hired contractors), without the need to report the construction to government. Many houses built that way were unauthorised constructions. The lack of cohesive design and construction standards for compliance also added to the cacophony of colours and forms in the space (Fig. 6c). Other dissonances in the landscape result from urban and architectural analysis for the decisions on building conditions incorrectly conducted.

The types of pressure that strongly influence spatial disorder in the Polish Carpathians are mass tourism and the related creation of ski slopes in unsuitable locations. This phenomenon may result from the crisis of excessive tourism development planning, and more broadly from the crisis of spatial planning itself (Kistowski, Śleszyński 2010). Contrary to building dispersion, however, mass tourism has the characteristics of an island. We can see this especially in the Beskidy Zachodnie Mountains (Żywiecki County), located in the vicinity of the densely-populated Silesian conurbation, the Tatra Mountains and their foothills (Tatrzański County), the Pieniny Mountains (Nowosądecki County), and the pathways of the Bieszczady National Park (Bieszczadzki County). In the above-mentioned parts of the Carpathians, the number of overnight stays has been gradually increasing year by year (Tab. 2).

Tab 2. Number of nights spent by tourists (GUS 2020). Source: own elaboration based on the Local Data Bank of the Central Statistical Office of Poland (GUS 2020).

\begin{tabular}{|c|c|c|c|c|c|}
\hline Year & $\mathbf{2 0 1 6}$ & $\mathbf{2 0 1 7}$ & $\mathbf{2 0 1 8}$ & $\mathbf{2 0 1 9}$ & $\begin{array}{c}\text { Increase } \\
\text { [\%] }\end{array}$ \\
\hline Voivodeship & 5450,366 & 5810,348 & 6315,306 & 6520,299 & $\mathbf{1 9 . 6}$ \\
\hline Silesian & 12354,154 & 13165,713 & 13918,770 & 14855,514 & $\mathbf{2 0 . 2}$ \\
\hline Lesser Poland & 3097,584 & 3384,948 & 3540,363 & 3602,108 & $\mathbf{1 6 . 3}$ \\
\hline Subcarpathian & 3090 \\
\hline County & 360,603 & 402,887 & 401,641 & 402,887 & $\mathbf{1 1 . 8}$ \\
\hline Żywiecki & 2618,559 & 2953,270 & 3201,319 & 2953,270 & $\mathbf{1 2 . 8}$ \\
\hline Tatrzański & 294,535 & 328,016 & 352,013 & 328,016 & $\mathbf{1 1 . 4}$ \\
\hline Bieszczadzki &
\end{tabular}


It should be emphasised, however, that since the 1990s, the change in the direction, size and structure of tourism has resulted in the advantage of short-stay tourism over long-term tourism, and the inhabitants of the northern foothills of the Carpathians are an important group of tourists. They also look for new destinations (Faracik et al. 2009). Various factors affect the attractiveness of individual places. The poorly-accessible Bieszczady Mountains are characterised by a unique landscape with mountain meadows; the Tatra Mountains are the only high mountain range in the country, and the Pieniny are relatively accessible and boast one of the most beautiful river gorges in Europe (the Dunajec River Gorge). In these places, tourist infrastructure overlays environmental and spatial factors. The load on the relatively small ecosystem of the Tatra National Park is 10,000 people per $\mathrm{km}^{2}$. In Pieniny National Park, this value reaches as many as 25,000 people per $\mathrm{km}^{2}$ (Więckowski 2010). Note that tourists in national parks mainly move along the defined routes (Fig. 6d), so environmental degradation there is linear and affects the landform, soil, water and vegetation. Ski runs negatively affect spatial order in two ways: by introducing adverse changes in abiotic elements of the environment, and by interrupting ecological corridors. The latter process is mainly due to obvious spatial and environmental reasons, with most areas suitable for downhill skiing lying 1,000 m above sea level (Łajczak 2005). Such areas are quite rare in the Polish Carpathians, being located mainly in the Tatra Mts., Podtatrze, Beskid Śląski, Żywiecki and Sądecki (Faracik et al. 2008), and are usually covered by natural forms of protection, which also protect the migration routes of animals. This can lead to strong spatial conflicts.

As discussed above, mass tourism in the Polish Carpathians leads to the degradation of the environment in a natural sense, but also in an extra-natural sense by adversely affecting the visual value of the landscape in the tourist centres and around access roads, due to the above-described cluttering of the landscape with outdoor advertising and inconsistently-styled architecture.

\subsection{Relations of pressure types to sustainable development dimensions (impact)}

Almost all types of pressure influence the three dimensions of sustainable development. Among the 52 manifestations of this pressure (state), nine violated all three of the dimensions analysed (Tab. 1). These nine symptoms of spatial disorder can be considered the least compatible with the idea of sustainable development.

The main negative phenomenon that has social, economic and environmental effects is building dispersion. It significantly interferes with the proper functioning of the natural environment, mainly by interrupting the migration corridors of animals and by creating a larger volume of surface runoff. In an economic and social sense, it causes the loss of valuable landscape for tourism and areas attractive for transhumance, which may contribute to both the development of tourism and the preservation of biodiversity in pastoral clearings. The scattering of buildings can lead to the severing of social ties, as well as increased financial expenses incurred by the commune for infrastructure, and by its inhabitants for commuting.

Other negative phenomena that violate all three dimensions of sustainable development include development of buildings on sloped areas, cutting slopes with transport networks, building on floodplain terraces, and over-regulation of rivers. Such solutions can trigger landslides or periodic floods in river valleys, thereby entailing serious financial losses, leading to human tragedies, and increasing the frequency of catastrophic (abrupt) functioning of the environment, at the expense of slow evolutionary changes.

The urban sprawl phenomenon also cannot be ignored, since it interferes with natural suburban systems by decreasing their recreational values, and by increasing expenditures on infrastructure and commuting to cities. Other serious violations of the sustainable development principle are mass tourism and ski infrastructure, both leading to spatial conflicts and lowering the landscape quality. In the long term, these can lead to an outflow of wealthier tourists and a serious decline in the quality of the natural environment. 


\section{Conclusions}

The conclusions of this study are recommendations (responses) related to the methods of reducing both the causes and effects of spatial chaos (Tab. 1). It is neither simple nor unambiguous to answer the question of which factors most strongly influenced spatial disorder, particularly those visible in the scattering of buildings and the lack of spatial cohesion. One of the sources of the disorder is certainly economic and political change: the transformations after World War II and the systemic transformation in the 1990s, both severe in the mountainous areas, led to their impoverishment.

Currently, there are two main causes of this chaos. The first is spatial planning using flawed assumptions and poor execution; the second are the values prized by modern society. In mountainous areas, two direct sources of chaos seem to be the planning tool named 'decision on building conditions' and the lack of obligation to prepare local spatial development plans. Development of local plans should be particularly important in areas affected by urban sprawl. A comprehensive tool for organising space, such an organised plan, could not only stop the functional chaos in the suburbs, but also protect the natural systems of neighbouring cities. Planning documents themselves, however, may result in insufficient development without a reliable determination of the balance of land for development using a scientific method, and without an analysis of the financial consequences of adopting the plan.

One way to reduce spatial disorder in the Carpathians could be legislative changes regarding compliance of decisions on development conditions with the spatial policy of the commune (the study). Such a solution would be particularly effective if the quality of eco-physiographic studies were increased; to do so, people wishing to make such studies should first obtain the corresponding authorisation. Only then would the natural conditions become an actual basis for spatial planning in the mountains - not fictional or non-existent, as is currently the case. It is the mountainous areas where the natural conditions are particularly important in terms of spatial planning. To protect the landscape visual values it also seems a good idea to introduce similar documentation to the eco-physiographic studies (the landscape study). However, the use of acceptable architectural forms, an approach already practised in the Pieniny Mountains, could be an effective tool for reducing architectural chaos. A catalogue of such forms could constitute an attachment to the local plan.

Experts believe that the law is only as good as it is, based on the values shared by society. In this context, legal changes should be conducted in parallel with education among communities inhabiting the mountains. Such education should aim to convey the message that the multivariate values of the mountain landscape constitute the main development potential of these lands, within the context of the economics and factors threatening this potential. Such activities have already been undertaken in the Polish Carpathians for many years - for example, through programs financed by the European Union and Swiss Fund. These funds also aim to support the preservation of the natural and cultural heritage of the Carpathians. A systemic solution seems necessary, however, and could be implemented by introducing a national fund supporting extensive, non-invasive management methods in mountainous areas, making it possible to execute the consolidation process in areas with an excessively fragmented agrarian structure.

Subsidised organic farming also presents an opportunity to maintain agriculture that is noninvasive for the mountain environment. This could be supported by the abovementioned land consolidation process (Czudec, Zając 2017). O'Rourke (2019) sees a similar need in Ireland for state support of pastoral mountain areas. While socioeconomic problems related to the lack of profitability of mountain farming can be solved with financial programs, the strong environmental pressure applied by mass tourism requires other remedial measures. Sustainable tourism was widely discussed in the Carpathian Convention (2003) and the accompanying documents: Protocol on Sustainable Tourism to the Framework Convention on the Protection and Sustainable Development of the Carpathians (2011) and Strategy for Sustainable Tourism Development of the Carpathians (2014). As a remedy, these documents proposed to redirect some of the tourist load from tourist centres to neighbouring and less densely populated areas. Kistowski and Śleszyński (2010) offered a similar solution to this problem in the Tatra Mountains and Podtatrze. In addition, based on a case study in the Apennines in Italy, Forleo et al. (2017) indicated that 
the diversity of tourism types in one place can increase the chances of preserving the protective functions of the area and prevent its degradation. This approach could be adapted to the Polish Carpathians. Consider downhill skiing, which is popular in the region. Except for the Tatra Mountains and Podtarze, the Carpathians do not offer good conditions for this sport. However, they do offer very good conditions for cross-country skiing and ski-touring, and so developing devoted trails and promoting these types of skiing can help to move the focus from downhill skiing to cross-country skiing and ski-touring, with a positive effect on the environment. It is also important to create tourism development strategies that are not only professional, but also take into account social dialogue, thereby increasing their chances of success (Zawilińska, Szpara 2016).

\section{Academic references}

[1] Affek, A. N. (2019). Wpływ gospodarki leśnej na terenach górskich na wybrane elementy środowiska - aktualny stan wiedzy. Przegląd Geograficzny 91(1), 63-81. DOI: 10.7163/PrzG.2019.1.3.

[2] Affek, A. N., Garlee, A., Sosnowska, A. \& Zachwatowicz, M. (2019). Oszacowanie skali wpływu pozyskiwania drewna na wybrane elementy środowiska we wschodniej części polskich Karpat. Przegląd Geograficzny 91(1), 83-106. DOI: 10.7163/PrzG.2019.1.4.

[3] Bański, J. \& Stola, W. (2002). Przemiany struktury przestrzennej i funkcjonalnej obszarów wiejskich w Polsce. Warszawa: Committee of Rural Areas, Polish Geographical Society, Institute of Geography and Spatial Organization, Polish Academy of Sciences.

[4] Bański, J. \& Wesołowska, M. (2020). Disappearing villages in Poland - selected socioeconomic processes and spatial phenomena. European Countryside 12(2), 221-241. DOI: 10.2478/euco-2020-0013.

[5] Brańka, P. (2015). Zróżnicowanie rozwoju obszarów wiejskich w woj. małopolskim. Studia KPZK 161, 362-370.

[6] Brunori, E., Salvati, L., Mancinelli, R. \& Biasi, R. (2016). Multi-temporal land use and cover changing analysis: the environmental impact in Mediterranean area. The International Journal of Sustainable Development and World Ecology 24(3), 276-288. DOI: 10.1080/13504509.2016.1205156.

[7] Bylak, A., Kukuła, K. \& Kukuła E. (2009). Influence of regulation on ichthyofauna and benthos of the Różanka stream. Ecohydrology \& Hydrobiology 9(2-4), 211-223. DOI: 10.2478/v10104-010-0006-z.

[8] Bystřický, V., Moravcová, J., Polenský, J. \& Pečenka, J. (2017). Land use changes in the last half century and their impact on water retention in the Šumava Mountains and Foothills (Czech Republic). European Countryside 9(1), 116-131. DOI: 10.1515/euco-2017-0007.

[9] Castro, H., Lehsten, V., Lavorel, S. \& Freitas, H. (2010). Functional response traits in relation to land use change in the Montado. Agriculture, Ecosysems and Environment 137(1-2), 183191. DOI: $10.1016 / \mathrm{j}$.agee.2010.02.002.

[10] Ciepiela, A. \& Łasocha, M. (2020). Urban sprawl and spatial planning documents: the case of the municipality of Biecz, Poland. Space and Form/Przestrzeń i Forma 44, 231-248. DOI: 10.21005/pif.2020.44.C-03.

[11] Cieszewska, A. (2019). Green belts. Zielone pierścienie wielkich miast. Warszawa: Wyd. Akad. Sedno.

[12] Czudec, A. \& Zając, D. (2017). Non-farming entrepreneurship in the farm activity diversification process. Journal of Agribusiness and Rural Development 43(1), 69-78. DOI: 10.17306/J.JARD.2017.00208.

[13] Ćwik, A. (2013). Rozwój zrównoważony a konflikty w potencjalnym zagospodarowaniu górskiego terenu podmiejskiego. Studia KPZK PAN 152, 198-206. 
[14] Ćwik, A. (2014). Zastosowanie metody „trzech pytań“ w planowaniu rozwoju zrównoważonego korytarza Wisłoka w Rzeszowie. Journal of Civil Engineering, Environment and Architecture 61(3/l), 53-61. DOI: 10.7862/rb.2014.46.

[15] Ćwik, A. \& Ortyl, B. (2016). Rozproszona zabudowa w górach - utracone krajobrazy? In Gajdek A., Sołtysik A. \& Wójcik A., eds., Krajobraz Polski. Cudze Chwalicie. Ochrona i kształtowanie rodzimego krajobrazu (pp. 165-175). Rzeszów: University of Rzeszów.

[16] Durydiwka, M. (2012). Czynniki rozwoju i zróżnicowanie funkcji turystycznej na obszarach wiejskich w Polsce. Warszawa: University of Warsaw.

[17] Durydiwka, M. (2013). Tourist function in rural areas of Poland. Spacial diversity and changing trends. Miscellanea Geographica 17(3), 5-11. DOI: 10.2478/v10288-012-0041-2.

[18] Ekins, P. (2000). Economic Growth and Environmental Sustainability. The Prospects for Green Growth. London-New York: Routledge.

[19] Faracik, R., Kurek, W., Mika, M., Pawlusiński, R. (2009). Turystyka w Karpatach Polskich w świetle współczesnych kierunków rozwoju. In Domański, W. B., Kurek, W., eds., Gospodarka i przestrzeń (pp. 77-97). Kraków: Jagiellonian University.

[20] Forleo, M. B., Giaccio, V., Giannelli, A., Mastronardi, L. \& Palmieri, N. (2017). Socioeconomic drivers, land cover changes and the dynamics of rural settlements: Mt. Matese area (Italy). European Countryside 9(3), 435-457. DOI: 10.1515/euco-2017-0026.

[21] Froehlich, W. \& Walling, D. E. (1997). The role of unmetalled roads as a sediment source in the fluvial systems of the Polish Flysch Carpathians. In Walling, D. E. \& Probst, J. L., eds., Human Impact on Erosion and Sedimentation (pp. 159-168). Wallingford: IAHS.

[22] Gari, R. S., Newton, A. \& Icely, J. D. (2015). A review of the application and evolution of the DPSIR framework with an emphasis on coastal social-ecological systems. Ocean \& Coastal Management 6(4), 63-77. DOI: 10.1016/j.ocecoaman.2014.11.013.

[23] García-Ruiz, J. M. \& Lana-Renault, N. (2011). Hydrological and erosive consequences of farmland abandonment in Europe, with special reference to the Mediterranean region a review. Agriculture, Ecosystems and Environment 140(3-4), 317-338. DOI: 10.1016/j.agee.2011.01.003.

[24] Gibas, P. \& Heffner, K. (2018). Społeczne i ekonomiczne koszy bezładu przestrzeni osadnictwo obszarów wiejskich. Studia KPZK PAN 182(2), 163-195.

[25] Halfacree, K. (2012). Heterolocal Identities? Counter-Urbanisation, Second Homes, and Rural Consumption in the Era of Mobilities. Population, Space and Place 18(2), 209-224. DOI: $10.1002 / p s p .665$.

[26] Haughton, G. \& Counsell, D. (2004). Regions, Spatial Strategies and Sustainable Development. London-New York: Routledge.

[27] Hrehorowicz-Gaber, H. (2019). Współczesne przemiany i rozwój struktur przestrzennych w Karpatach uwarunkowania i modele rozwoju. Kraków: Publishing House of the Kraków University of Technology.

[28] Kistowski, M. \& Śleszyński, P. (2010). Presja turystyczna na tle walorów krajobrazowych Polski. Krajobraz i turystyka 14, 36-51.

[29] Kowalczyk, A. (1990). Badania geograficzne osadnictwa letniskowego w strefie górskiej w wybranych krajach europejskich. Acta Universitas Lodziensis. Turyzm 6, 21-41.

[30] Kozak, J. (2010). Forest cover changes and their drivers in the Polish Carpathian Mountains since 1800. In Nagendra, H. \& Southworth, J., eds., Reforesting Landscapes: Linking Pattern and Process (pp. 253-273). Dordrecht, London, New York: Springer Netherlands. DOI: $10.1007 / 978-1-4020-9656-3$.

[31] Kroczak, R., Bryndal, T., Bucała, A. \& Fidelus, J. (2016). The development, temporal evolution and environmental influence of an unpaved road network on mountain terrain: 
an example from the Carpathian Mts. (Poland). Environment Earth Sciences 75, Art. 250. DOI: $10.1007 / \mathrm{s} 12665-015-5055-6$.

[32] Kuemmerle, T., Hostert, P., Radeloff, V. C., van der Linden, S., Perzanowski, K. \& Kruhlov, I. (2008). Cross-border comparison of post-socialist farmland abandonment in the Carpathians. Ecosystems 11, 614-628. DOI: 10.1007/s10021-008-9146-Z.

[33] Listwan-Franczak, K. \& Franczak, P. (2015). Problematyka reklamy zewnętrznej na obszarach cennych przyrodniczo, przykład otoczenia Tatr. Prace Geograficzne 142, 57-75. Kraków: Jagiellonian University. DOI: 10.4467/20833113PG.15.018.4458.

[34] Łajczak, A. (2005). Wpływ narciarstwa na modelowanie stoków górskich, na przykładzie Pilska. In Łajczak A., ed., Antropopresja w górach średnich strefy umiarkowanej i skutki geomorfologiczne, na przykładzie wybranych obszarów Europy Środkowej (pp. 47-57). Sosnowiec: Wydział nauk o Ziemi Uniwersytetu Uniwersytetu Ślaskiego.

[35] MacDonald, D., Crabtree, J. R., Wiesinger, G., Dax, T., Stamou, N., Fleury, P., Gutierrez Lazpita, J. \& Gibon, A. (2000). Agricultural abandonment in mountain areas of Europe: environmental consequences and policy response. Journal of Environmenal Managagement 59(1), 47-69. DOI: 10.1006/jema.1999.0335.

[36] Marini, L., Fontana, P., Battisti, A. \& Gaston, K. J. (2009). Response of orthopteran diversity to abandonment of semi-natural meadows. Agriculture Ecosysems Environment 132(3-4), 232-236. DOI: 10.1016/j.agee.2009.04.003.

[37] Maxim, L., Spangenberg, J. H. \& O'Connor, M. (2009). An analysis of risks for biodiversity under the DPSIR framework. Ecological Economics 69(1), 12-23. DOI: 10.1016/j.ecolecon.2009.03.017.

[38] Mika, M. \& Faracik, R. (2008). Second homes as a factor of the transformation of rural areas in the Polish Carpathians. Folia Geographica 12, 245-255.

[39] Munteanu, C., Kuemmerle, T., Boltiziar, M., Lieskovský, J., Mojes, M., Kaim, D., KonkolyGyuró, É., Mackovčin, P., Müller, D., Ostapowicz, K. \& Radeloff, V. C. (2017). Nineteenthcentury land-use legacies affect contemporary land abandonment in the Carpathians. Regional Environmental Change 17, 2209-2222. DOI: 10.1007/s10113-016-1097-x.

[40] Munton, R. \& Collins, K. (1998). Government Strategies for Sustainable Development. Geography 83(4), 346-357.

[41] O'Rourke, E. (2019). Drivers of land abandonment in the Irish Uplands: a case study. European Countryside 11(2), 211-228. DOI: 10.2478/euco-2019-0011.

[42] Ortyl, B., Ćwik, A. \& Kasprzyk, I. (2018). What happens in a Carpathian catchment after the sudden abandonment of cultivation? Catena 166, 158-170. DOI: 10.1016/j.catena.2018.04.002.

[43] Plesiński, K., Bylak, A., Radecki-Pawlik, A., Mikołajczyk, T. \& Kukuła, K. (2018). Possibilities of fish passage through the block ramp: Model-based estimation of permeability. Science of the Total Environment 631-632, 1201-1211. DOI: 10.1016/j.scitotenv.2018.03.128.

[44] Pollack, M. (2011). Cesarz Ameryki. Wielka ucieczka z Galicji. Wołowiec: Wyd. Czarne.

[45] Prince, H. E., Bunce, R. G. H. \& Jongman, R. H .G. (2012). Changes in the vegetation composition of hay meadows between 1993 and 2009 in the Picos de Europa and implications for nature conservation. Journal of Nature Conservation 20(3), 162-169. DOI: 10.1016/j.jnc.2012.01.002.

[46] Pullanikkatil, D., Palamuleni, L. \& Ruhiiga, T. (2016). Assessment of land use change in Likangala River catchment, Malawi: A remote sensing and DPSIR approach. Applied Geography 71, 9-23. DOI: 10.1016/j.apgeog.2016.04.005.

[47] Rinaldi, M., Wyżga, B. \& Surian, N. (2005). Sediment mining in alluvial channels: physical effects and management perspectives. River Research and Application 21(7), 805-828. DOI: $10.1002 /$ rra.884. 
[48] Rosner, A. (2016). Współczesne procesy zmian zaludnienia obszarów wiejskich w Polsce. Studia KPZK PAN 167, 232-249.

[49] Serafin, P. (2017). Zmiany w użytkowaniu gruntów oraz gęstość zabudowy na styku miasto - obszar wiejski jako przejawy suburbanizacji Nowego Sącza. Research Papers of Wrocław University of Economics 467, 102-112. DOI: 10.15611/pn.2017.467.09.

[50] Senetra, A., Szczepańska, A. \& Wasilewicz-Pszczółkowska, M. (2014). Analysis of changes in the land use structure of developed and urban areas in Eastern Poland. Bulletin of Geography. Socio-economic Series, 24, 219-230. DOI: 10.2478/bog-2014-0024.

[51] Solon, J., Borzyszkowski, J., Bidłasik, M., Richling, A., Badora, K., Balon, J., BrzezińskaWójcik, T., Chabudziński, Ł., Dobrowolski, R., Grzegorczyk, I., Jodłowski, M., Kistowski, M., Kot, R., Krąż, P., Lechnio, J., Macias, A., Majchrowska, A., Malinowska, E., Migoń, P., MygaPiątek, U., Nita, J., Papińska, E., Rodzik, J., Strzyż, M., Terpiłowski, S. \& Ziaja, W. (2018). Physico-geographical mesoregions of Poland: Verification and adjustment of boundaries on the basis of contemporary spatial data. Geographia Polonica 91(2), 143-170. DOI: 10.7163/GPol.0115.

[52] Soja, M. (2008). Cykle rozwoju ludności Karpat Polskich w XIX i XX wieku. Kraków: Jagiellonian University.

[53] Spanò, M., Gentile, F., Davies, C. \& Lafortezza, R. (2017). The DPSIR framework in support of green infrastructure planning: A case study in Southern Italy, Land Use Policy 61, 242250. DOI: 10.1016/j.landusepol.2016.10.051.

[54] Svarstad, H., Petersen, L. K., Rothman, D., Siepel, H. \& Wätzold, F. (2008). Discursive biases of the environmental research framework DPSIR. Land Use Policy 25, 116-125. DOI: 10.1016/j.landusepol.2007.03.005.

[55] Śleszyński, P. (2012). Stan prac planistycznych w kraju. In Śleszyński, P., Komornicki, T., Solon, J. \& Więckowski, M., eds., Planowanie przestrzenne w gminach (pp. 11-58). Warszawa: Wyd. Akademickie Sedno.

[56] Śleszyński, P., Markowski, T. \& Kowalewski, A. (2018). Studia nad chaosem przestrzennym. Cz.3. Synteza. Uwarunkowania, skutki i propozycje naprawy chaosu przestrzennego. Studia KPZK PAN 182(3), 1-224.

[57] Śleszyński, P., Kowalewski, A., Markowski, T., Legutko-Kobus, P. \& Nowak, M. (2020). The Contemporary Economic Costs of Spatial Chaos. Evidence from Poland. Land 9(7), 214. DOI: $10.3390 /$ land9070214.

[58] Tasser, E., Walde, J., Tappeiner, U., Teutsch, A. \& Noggler, W. (2007). Land-use changes and natural reforestation in the Eastern Central Alps. Agriulture, Ecosystems, Environment 118, 115-129. DOI: 10.1016/j.agee.2006.05.004.

[59] Theissen, T., Otte, A. \& Waldhardt, R. (2019). Land-use change related to topography and societal drivers in high-mountains - a case study in the upper watershed of the Tergi (Kazbegi region), Greater Caucasus. European Countryside 11(3), 317-340. DOI: 10.2478/euco-2019-0020.

[60] Trzeszczyńska, P. (2015). The Lemko land remembered: about the research on the memory of the Lemkos in Poland and Ukraine. Anthropology of East Europe Review 33(2), 1-25.

[61] Venkatesh, G. (2010). Triple Bottom Line Approach to Individual and Global Sustainability. Problemy ekorozwoju 5(2), 25-37.

[62] Węcławowicz-Bilska, E. (2009). Uwarunkowania planowania przestrzennego na terenach górskich na przykładzie Polskich Karpat, Czasopismo Techniczne. Architektura 106 (2-A), 3-17.

[63] Więckowski, M. (2010). Turystyka na obszarach przygranicznych Polski. Warszawa: Inst. of Spatial Geography and Spatial Organization, Polish Academy of Sciences. 
[64] Wolski, J. (2016). The landscape of abandoned villages in the Western Bieszczady: the problem of definition and classification. Geographia Polonica 89(3), 371-387. DOI: 10.7163/GPol.0064.

[65] Wyżga, B., Zawiejska, J., Radecki-Pawlik, A. \& Hajdukiewicz, H. (2012). Environmental change, hydromorphological reference conditions and the restoration of Polish Carpathian rivers. Earth Surface Processes and Landforms 37(11), 1213-1226. DOI: 10.1002/esp.3273.

[66] Zawiejska, J., Wyżga, B., Radecki-Pawlik, A., (2015). Variation in surface bed material along a mountain river modified by gravel extraction and channelization, the Czarny Dunajec, Polish Carpathians. Geomorphology 231, 353-366. DOI: 10.1016/j.geomorph.2014.12.026.

[67] Zawilińska, B. (2020). Residents' attitudes towards a national park under conditions of suburbanisation and tourism pressure: a case study of Ojców National Park (Poland). European Countryside 12(1),119-137. DOI: 10.2478/euco-2020-0007.

[68] Zawilińska, B. \& Szpara, K. (2016). Participative model of tourism development planning in a region of high natural value: a case study of The Polish Carpathians. Scientific Review of Physical Culture, 5(4), 242-253.

Other sources

[69] CC (2003). Framework Convention on the Protection and Sustainable Development of the Carpathians. [Online] Available at: http://www.carpathianconvention.org/text-of-theconvention.html (Accessed 17.07.2020).

[70] EEA (1995). European Environment Agency. Europe's Environment: the Dobris Assessment. Copenhagen: EEA.

[71] European Commission (2010). EUROPE 2020. A strategy for smart, sustainable and inclusive growth. Communication From The Commission. 3.3.2010, COM (2010) 2020, p. 132. Brussels.

[72] GUS (2018). Główny Urząd Statystyczny. Indicators of territorial accessibility of Poland's residents to selected public utilities. Final report. [Online] http://stat.gov.pl (Accessed 24.07.2020).

[73] GUS (2020). Główny Urząd Statystyczny. Bank danych lokalnych [Online] https://bdl.stat.gov.pl/ (Accessed 21.12.2020).

[74] Holten-Andersen, J., Paalby, H., Christensen, N., Wier, M. \& Andersen, F. M. (1995). Recommendations on strategies for integrated assessment of broad environmental problems. Report submitted to the European Environment Agency (EEA) by the National Environmental Research Institute (NERI). Denmark.

[75] Karpacka Przestrzeń (2019). Project: Planowanie przestrzenne jako narzędzie ochrony przyrody w Karpatach. Ekopsychologia. [Online] https://karpackaprzestrzen.pl (Accessed 28.07.2020).

[76] Kowalewski, A., Mordasewicz, J., Osiatyński, J., Regulski, J., Stępień, J. \& Śleszyński, P. (2013). Raport o ekonomicznych stratach i społecznych kosztach niekontrolowanej urbanizacji w Polsce (Economic Losses and Social Costs of Uncontrolled Urbanization in Poland). Warszawa: Fundacja Rozwoju Demokracji Lokalnej, IGiGP PAN. [Online] https://frdl.org.pl/badania-i-analizy/raporty-i-inne/raport-o-ekonomicznych-stratach-ispolecznych-kosztach-niekontrolowanej-urbanizacji-w-polsce (Accessed 28.07.2020).

[77] OECD (2003). OECD Environmental Indicators: Development, Measurement and Use. Paris.

[78] Protocol on Sustainable Tourism to the Framework Convention on the Protection and Sustainable Development of the Carpathians (2011). [Online] Available at: http://www.carpathianconvention.org/protocol-on-sustainable-agriculture-and-ruraldevelopment.html (Accessed 23.07.2020). 
[79] Rączkowski, W. (2007). Zagrożenia osuwiskowe w polskich Karpatach. Paper presented at the conference: GEORISKS - risk reduction, awareness raising - 5th International Geological Fair. Warszawa, 30 May 2007. [Online] Available at: https://www.pgi.gov.pl/gdansk/geologia-morza-i-wybrzeza/opracowania/131-kopalniawiedzy-nowe/zagroenia-geologiczne/1554-geozagroienia-karpackieosuwiska.html? showall=1 (Accessed 27.07.2020).

[80] Strategy for Sustainable Tourism Development of the Carpathians (2014). UNEP/CC/COP4/DOC14. [Online] Available at: http://www.carpathianconvention.org/tl_files/carpathiancon/Downloads/03\%20Meetings $\% 2$ 0and\%20Events/COP/2014_COP4_Mikulov/WORKING\%20DOCUMENTS/DOC14_Carpat hian\%20Convention\%20Sustainable\%20Tourism\%20Strategy_updated.pdf (Accessed 23.07.2020).

[81] Smeets, E. \& Weterings, R. (1999). Environmental Indicators: Typology and Overview. European Environment, Technical Report No. 25. Office for Official Publications of the European Communities. European Environmental Agency. Copenhagen. [Online] Available at: http://www.eea.europa.eu/publications/TEC25 (Accessed 17.07.2020).

[82] Śleszyński, P. (2015). Szacunek chłonności demograficznej dla obszaru Polskich Karpat. Presentation: Chaos przestrzenny - ukryte koszty oraz utracone szanse. Karpaty łączą mechanizm konsultacji i współpracy dla wdrażania Konwencji Karpackiej. II Forum Karpackich Gmin. Sromowce Niżne 24.09.2015. [Online] https://docplayer.pl/187054198Karpaty-lacza-mechanizm-konsultacji-i-wspolpracy-dla-wdrazania-konwencjikarpackiej.html (Accessed 28.07.2020).

[83] UNEP (2002). United Nations Environment Program. Global Environmental Outlook 3. Earthscan. London: UNEP.

[84] Ustawa (2003). Ustawa z 27 marca 2003 r. o planowaniu i zagospodarowaniu przestrzennym. Dz.U. 2003, Nr 80, poz. 717. [Online] Available at: https://isap.sejm.gov.pl/isap.nsf/DocDetails.xsp?id=WDU20030800717 $\quad$ (Accessed 31.07.2020).

[85] WCED (1987). World Commission od Environment and Development. Our Common Future. Oxford: Oxford University Press. 